\title{
Complaint Management in the Public Sector Organization in the Philippines
}

\author{
Allan V. Mantaring \\ Department of Public Works and Highways Second Engineering District, Cabanatuan City, Philippines \\ Ma. Angela P. Espinoza \\ $7^{\text {th }}$ Infantry Division Philippine Army,Fort Magsaysay, Palayan City \\ Arneil G. Gabriel \\ Department of Public Administration, Nueva Ecija University of Science and Technology ,Philippines
}

\begin{abstract}
Participatory governance is a democratic process intended to involve citizens in the management of public institution. By providing them platforms through which they can access the government, transparency and accountability in public governance is enhanced. The Department of Public Works and Highways (DPWH) acknowledges its importance through the establishment of different platforms of communications wherein clients can raise their concerns. The study aims at describing and evaluating the Complaints Management Program of the DPWH Nueva Ecija $2^{\text {nd }}$ District Engineering Office based in Cabanatuan City. The analysis was drawn from Fifteen (15) client feedbacks received in 2017. The data were gathered using qualitative and quantitative approaches while multi-stakeholders framework for complaint management was adapted to measure the effectiveness of the feedback and complaint management mechanisms of the agency. The study found that the agency : a) institutionalizes and observes procedures in handling complaints; b) resolves complaints based on the principles of fairness, accessibility, responsiveness, efficiency, trust and citizens participation; however, there are limitations identified in regard to the administrative support in terms of personnel assigned, training and availability of vehicle use to verify various complaints on the ground. Civic engagement is an effective tool to promote democracy and enhance open government. They are proven to create enabling environment that tends to yield positive political outcomes and policy implementation results.
\end{abstract}

Keywords: Participatory governance, Complaint management ,Feedback mechanism, DPWH -Philippines

DOI: $10.7176 / \mathrm{PPAR} / 9-2-03$

\section{Introduction}

Participatory governance is a democratic process intended to involve citizens in the management of public institution. It bridges ordinary citizens and public institution making the latter effective and efficient in the delivery of public services (Palumbo,2017). The mechanisms for participatory governance may come in several platforms. It can be through actual participation in policy making; coproduction of public goods, co-governance through monitoring and evaluating programs or activities implemented by a government agency. Citizens complaints and feedback mechanism is one facet of participatory governance which makes the government more effective and responsive to public needs and demands both in the policy and political arenas

The Department of Public Works and Highways (DPWH) is a public sector organization considered as the engineering and construction arm of the Government and is one (1) of the three (3) National Government Agencies that implement infrastructure projects. Under its mandate, the DPWH is responsible for the planning of infrastructures, such as national roads and bridges, flood control, water resources projects and other public works, as well as the design, construction, and maintenance of national highways and bridges, and major flood control systems.

But the construction of several infrastructure projects often entails concerns and complaints from the public and proposed project end-users and often, these concerns were relayed through the different platforms of communications that the agency maintains. Among the common complaints raised by the public were the quality of the infrastructure projects, delays in project completion, perceived corruption and legal issues about the right-of-way acquisition.

In the publication Guidelines for Complaint Management in Organizations (Standards Australia, 2014), it was stated that complaint is said to be a demonstration of dissatisfaction made by the stakeholders to an organization, related to its products, people, and services. It may also arise from the way a complaint is handled or managed, wherein a response is explicitly or indirectly required or expected.

A system for accommodating complaints from stakeholders is maintained by National Government Agencies that is easily accessible and readily available 24/7. The Department of Public Works and Highways introduced several platforms in accepting and managing complaints and ensured that even the most vulnerable people who are more likely to encounter problems or concerns with the agency, can easily raise their concerns 
without going through a complicated complaints system that is often employed or utilized by other agencies.

By virtue of Memorandum Circulars No.53 issued on May 21, 2014 Front Desk Officers at the Front Desk Lobby of each Regional and District Engineering Office during office hours are designated. In a separate Memorandum dated July 17, 2017, the Department Information Officer (DIO) was similarly designated as the Authorized Spokesperson of the District Engineering Office along with the District Engineer and the Assistant District Engineer. However, it is interesting to note that in the issuances made by the two agency heads, the scope of work as well as the criteria in selecting the designated DIO were never mentioned. Further, the Qualification Standard for the said position was not identified. Also, the issuance made by Sec. Villar in Designating DIO's seems to be contradicting specific provisions of Department Orders No. 22 and 32, both issued on February 28, 2017, which was signed by Undersecretary Raul C. Asis as Officer-In-Charge. Department Order No. 22, Implementation of the Quality Management System (QMS) Manual in conformance with the requirements of ISO 9001:2015, and Department Order No. 32 or the Issuance of a Standard Procedures Manual for the Regional and District Engineering Offices, clearly identified that the Administrative Aide VI (Clerk III) Position under the Office of the District Engineer was reclassified as the Public Information Staff and tasked to carry-out information dissemination, manage media-related activities, responsible in coordinating with Civil Society Organizations and in the implementation of efficient customer feedback management.

\subsection{Complaints Management}

An effective complaint handling system is fundamental to delivering quality public services. According to Tang, complaints handling is a sign of good governance. This is not only dependent on having well-trained frontline personnel, but the management must also possess the commitment and understanding of the concerns raised by stakeholders. A complaint is an opportunity to improve and a lesson for reference (A Guide to Complaints Handling and Public Enquiries, 2009). Complaint management is fact-finding to establish the truth, being fair to all complainants and staff and that senior management commitment is essential to guide and support frontline staff.

The present study deals with the analysis of an agency complaint management system. The lack of available literature contextualized in the local setting prompted the researcher to assess and review the effectiveness and framework adapted to handle complaints by the management of a public organization. This academic paper adds literature on the subject matter. In general, the study sought answer to the following questions : (1) What are the institutional procedures observed by the Department of Public Works and Highways-Nueva Ecija 2nd District Engineering Office in the Philippines in managing complaints?; (2) how effective is the Department of Public Works and Highways-Nueva Ecija 2nd District Engineering Office in handling complaints using the multi stakeholders framework of analysis;(3) What are the limitations of the Nueva Ecija $2^{\text {nd }}$ District Engineering Office in managing complaints as perceived by the staff and clienteles?

\section{Methodology}

\section{The Study Design}

To analyze the Customer Feedback Management Program of DPWH Nueva Ecija $2^{\text {nd }}$ District Engineering Office, specifically on how it managed complaints, the mixed methods research design was used in this study. The "mixed methods" pertains to a developing methodology of research that integrates qualitative and quantitative facts within a single study. The fundamental principle is that such integration allows a more comprehensive and synergistic use of data rather than having a separate quantitative and qualitative data collection and analysis.(Agency for Healthcare Research and Quality, 2013) Johnson and Turner (2003) have argued that the important basis of this method of research is that several types of information or figures are to be collected using different approaches that allow mixed-methods study to offer insights not thinkable when only qualitative or quantitative data are gathered. Further, the objective of using this method of research is not to replace either of these approaches but to use a multiple approach in finding answers to research questions.(Johnson and Onwuegbuzie, 2004).

The research question number one shall be discussed and analyzed using descriptive qualitative data gathering tool. While statement of the problem number two measures the effectiveness of the agency mechanism on complaint and feedback by adapting the research paradigm and using mixed method of research. Finally, perceived limitations in the handling of complaints are identified and determined by means of personal observation, field interview and document analysis.

\section{The Respondents}

The researcher conducted a personal interview by soliciting information from the Regional Public Affairs and Information Officer based at the DPWH Regional Office in City of San Fernando, Pampanga, who has direct supervision on the activities and functions of the District Information Officer of the DPWH Nueva Ecija 2nd District Engineering Office. Through the interview method, the researcher was able to gather pertinent data 
relative to this study. Additional data were gathered from different records, DPWH Department Orders and Memorandum Circulars as additional support for the needed information. The complaints received by the District Engineering Office in CY 2017 were also analyzed and reviewed for timeliness and appropriateness of responses.

\section{The Research Paradigm}

There are five (5) elements essential to efficient complaint handling according to the Better Practice Guide to Complaint Handling published by the Commonwealth Ombudsman, Canberra, Australia on April 2009 and these are shown on Figure 1. Few modifications are made to suit to the local context to wit;

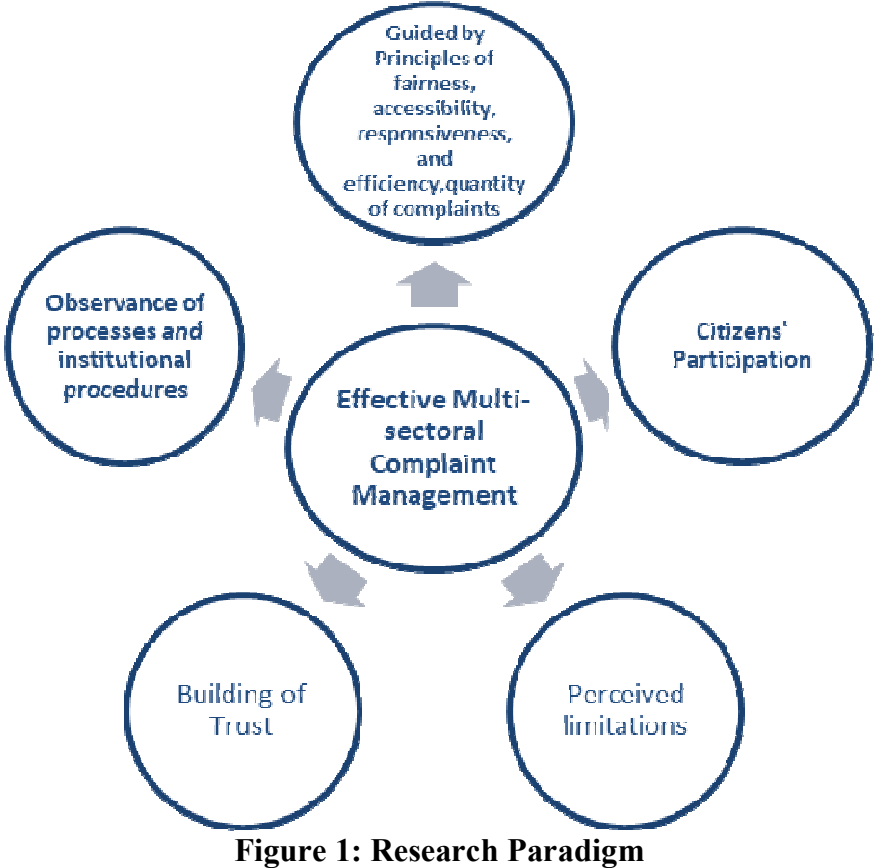

Inherent in all systems is the legal -rational basis of institutional program based upon well designed processes and procedures to ensure effective implementation. In like manner, effective multi- stakeholders complaints handling is guided by specific rules and regulations. The study looks into the processes and procedures and how these parameters are met in the analysis of the effectiveness of the complaint handling and management of the DPWH. A measure of effectiveness also includes observance of fairness, accessibility, responsiveness, and efficiency on the complaint mechanism and grievance resolution. Couple with citizen's participation, an effective feedback mechanism creates trust to the institution and the way it resolves issue pertaining to institutional operation. These are the parameters on how a multi- sectoral stakeholders complaints resolution works.

\section{Results and Discussion}

Multi-stakeholder's participation in the Customer Feedback Mechanism

Public governance is enhanced when the government is open. It also increases the degree of transparency and accountability of a public organization. Transparency and accountability as elements of good governance, are proven to increase component cities local legislative performance (Gabriel,2016; Ong and Gabriel (2018) and linked to the development of trust in public institution when practice and observed(Gabriel and Gutierrez,2017). The twin principles are also proven to enhance local legislators' performance in terms of legislative outputs (Gabriel, 2017).

Transparency and accountability enhances open government. The public is now aware of their rights and the responsibilities of each National Government Agency and its specific departments and even employees. With the implementation of various transparency and reform measures such as the Anti-Red Tape Act and the Presidential Complaints Center, the general public expects all agencies involved in public service to address their concerns promptly and efficiently. And can demand for the quality of service they deserved.

An efficient and effective management of complaints is vital in the delivery of quality service to the public (Accenture Institute for Public Service Value (AIPSV) (2008, it enhances the ability of the agency to improve service strategy and delivery (A Guide to Complaints Handling and Public Enquiries, 2009). It promotes greater efficiency, and increase staff morale as well as have a positive strengthens the reputation of the organization. 
Complaints mechanism promotes people's confidence and trust in Government institution. An effective complaint management consists of :

Observance of processes and institutional procedures

Good complaints handling requires listening, understanding, explaining and helping the stakeholders in its resolution wherever possible. Grievances must be addressed in a fair and professional manner, and responses must be communicated sincerely and promptly.

The DIO follows a systematic guide in the conduct of tasks for the purpose of implementing the social mobilization programs and projects of the Department to engage people's participation in all aspects of the project development cycle and to respond to customers' concerns and/or assess customer satisfaction through effective feedback mechanism. An approved process flow also identifies the responsibilities, point persons and action to be taken in the resolution of Complaints. The process of complaint resolution is shown below;

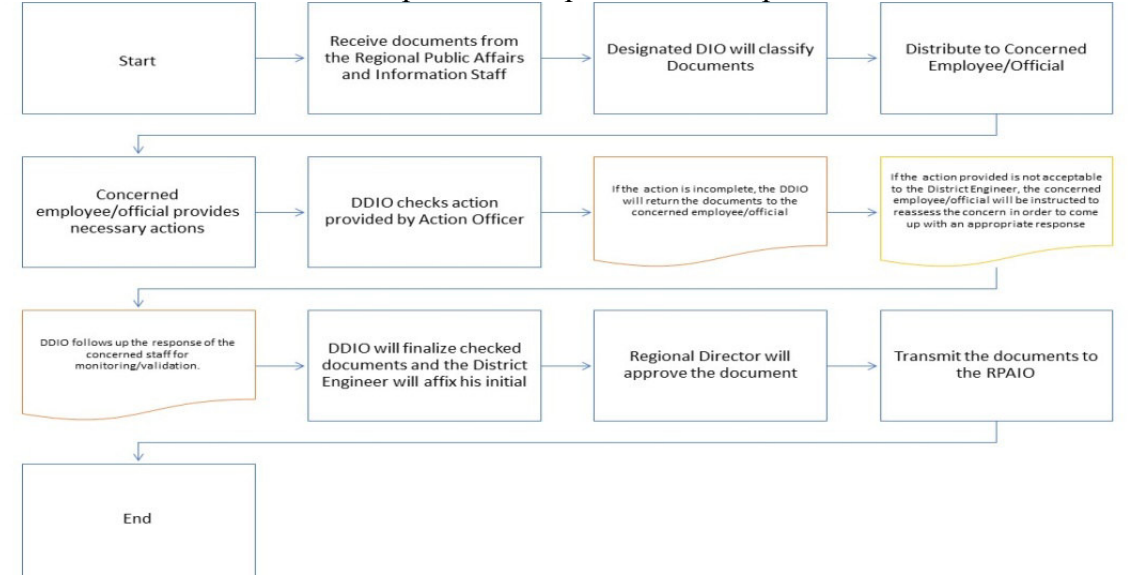

Figure 2 Process Flow

The role of the DIO in complaints management basically evolves in the receiving, classification, checking of response or actions, drafting of response in the agreed format and in the transmittal of the documents via electronic mail to the Regional Public Affairs and Information Office. The Regional Public Affairs and Information Officer explained that although replies to complaints are provided by the concerned employees or officials, the DIO must have a thorough understanding on the technical and legal components of the infrastructure projects which are often the cause of complaints. The DIO must know how to validate the appropriateness of the responses made, analyze complex complaints and customer feedback issues, has the ability to communicate effectively, and must have strong communication skills. The DPWH observes the process of handing complaints and institutionalizes the system.

Policy-making and implementation guided by the principles of fairness, accessibility, responsiveness, and efficiency

Fairness in complaints handling

A strong complaint handling system is built on the premise of fairness or treating all clients as equal and taking actions with utmost considerations. It requires a skilled employee incharge of complaint handling and a committed organization to resolve complaints. (Better Practice Guide to Complaint Handling, April 2009). Having an organization that values complaints and skilled professional that will handle complaint management are vital in maintaining an effective and responsive complaint handling system. Fairness in complaint handling also denotes consistent response to similar agency complaints independent of the differences in status, influence, and socio-political position in the life of the complainant. As reveals on Table 3, 93.33 percent of the complaints were acted upon and resolved by the agency regardless of socio-economic standing of the complainants.

\section{Accessibility and Presence of a designated District Information Officer}

The parameter of access refers to the availability of designated officer who resolves complaints on time and the assigned workplace space to ensure that particular office is devoted to complaints handling filed by walk in citizens or through the media platforms. According to Mrs. Adora DL. Sunga, Regional Public Affairs Information Officer, " there is a need to have a dedicated person that will handle the complaints" . The qualifications of the Designated DIO were contained in a Memorandum issued by Sec. Mark A. Villar dated July 17, 2017, i.e., the DIO must have the competency in managing the District's Citizens Feedback Management and community engagement. The DIO is also expected to be adept in the preparation of news and photo releases and must be familiar in the production of publications and handling of special projects. In a separate issuance dated July 17, 2017, the DIO was also appointed as the Authorized Spokesperson of the District Engineering Office 
along with the District Engineer and the Assistant District Engineer.The qualifications for the DIO rests also on the role of the information officer which requires a higher level of competence, training, skills and is capable to accomplish the said functions with professionalism since the DIO assumes a pivotal role in the image building, public relations and maintaining accord between the agency and its stakeholders.

At the Nueva Ecija $2^{\text {nd }}$ District Engineering Office, the DIO who is tasked to handle complaints management at the District Level is a 45-year-old male Registered Nurse who presently assumes the permanent position of Administrative Aide VI/Public Information Staff with a Salary Grade of 6. He is in charge with the publication of the quarterly newsletter, preparation of press and photo-releases, information and education campaign materials, preparation of office communications, accomplishment reports, planning and coordination of office activities, and in the operations of the Public Assistance and Complaints Desk.

Based on the Qualification Standards (Revised 1997) (Civil Service Commission, 1997), an Administrative Aide VI (Clerk III) must have completed two (2) years studies in college and must have Sub-professional Career Service Eligibility. In contrast, an Information Officer I, an ideal position for the District Information Officer, must have a Bachelor's Degree and Professional Career Service Eligibility.

The Nueva Ecija $2^{\text {nd }}$ District Engineering Office management took note the importance of the DIO functions and, on September 2017, a Job-Order staff was employed by the District Engineering Office to assist the DIO in the preparation of Audio-Visual Presentation materials and the conduct of photo and video coverages.

In 2017, the DIO was sent by the Regional Public Affairs and Information Officer (RPAIO) of DPWH Regional Office No. 3 to represent Central Luzon in the RPAIO Quarterly Advocacy and Planning Workshops organized by the Stakeholders Relations Service of the DPWH Central Office. It was only then that the DIO received institutional training on complaints handling and news writing which are two vital functions of the DIO. Though he was already mentored and trained by the DPWH Region III RPAIO during the preparation of annual reports, office publications and preparation of responses to complaints.

The Complaints Handling Officer is the most significant factor in guaranteeing that an organization's complaint handling system is responsive to complainants. The stakeholders are more likely to be satisfied with the complaint handling system if the person dealing with their complaint is unbiased and competent. He should also have the skills to perform his role with sensitivity and objectivity; be knowledgeable on all aspects of the organization's internal complaints procedure; be able to assist stakeholders in the preparation of written complaints specially if it comes from stakeholders who require special assistance; and have access to the different levels of the organization for quick resolution (Guidance for Complaint Handling Officers, 2010).

The DPWH Nueva Ecija $2^{\text {nd }}$ District Engineering Office must understand that complaint handling is an important role and that the DIO, should be given guidance and appropriate training in customer contact and effective communication. The local DPWH office may have hired the right person who can communicate the programs and activities of the agency but due to the technical nature of the infrastructure related complaints, organizational policies, and legal framework for handling complaints, the skills, education and work-related experience of the present DIO is deemed inadequate.

Further, Mrs. Sunga explained that in complaints management, the whole of the DPWH relies on coordination with the concerned subject of a complaint or the respective office. These are settled on a case to case basis. Internal concerns are handled by the Human Resources Administrative Section but the external issues that pass thru the Regional Public Affairs and Information Officer must be well coordinated, the reason why there is a need that the DIO is knowledgeable and trained in complaints management.

Based on interview, the District Information Officer in-charge of managing complaints from citizens is designated and assigned showing a general commitment on the part of the agency to resolve citizens' complaints. But the assigned DIO has to undergo training and skills development in complaint handling.

\section{Complaints Received and resolved}

In 2017, the Nueva Ecija $2^{\text {nd }}$ District Engineering Office received a total of fifteen (15) complaints that were channeled through the different platforms made available by the Department.

Among the eight (8) available channels, stakeholders relayed their grievances or requests to the three (3) most common platforms, i.e., letters, social media, and call center facility.

Four (4) or $26.67 \%$ of the complaints were letters sentto the DPWH Central Office, $33.33 \%$ or five (5) feedbacks were received from the call center facility of the Department and the Presidential Action and Complaints Center; and six (6) out of the fifteen (15) complaints (40\%) were grievances sent to the DPWH Official Facebook Page. The emergence of social media sites as the most utilized platform in sending feedback proved that this is the most accessible platform to all stakeholders, while there were no complaints received from walk-in clients, or those attended by the Front Desk Officer at the local DPWH office. 


\begin{tabular}{|c|c|c|c|}
\hline & Table 1. Number of Comp & aints Received in CY 2017 & \\
\hline Platform & $\begin{array}{l}\text { Total Number of } \\
\text { Feedbacks Resolved }\end{array}$ & $\begin{array}{l}\text { Total Number of } \\
\text { Feedbacks Unresolved }\end{array}$ & $\begin{array}{ll}\text { Total Number } & \text { of } \\
\text { Feedbacks Received } & \end{array}$ \\
\hline E-mail & 0 & 0 & 0 \\
\hline Phone-in & 0 & 0 & 0 \\
\hline Walk in/front Desk & 0 & 0 & 0 \\
\hline Text 2920 & 0 & 0 & 0 \\
\hline Letter referral & 4 & 0 & 4 \\
\hline Social Media & 6 & 0 & 6 \\
\hline Call center & 5 & 0 & 5 \\
\hline News Clipping & 0 & 0 & 0 \\
\hline Total & 15 & 0 & 15 \\
\hline
\end{tabular}

All the complaints received by the Nueva Ecija $2^{\text {nd }}$ District Engineering Office were reported resolved with a $100 \%$ resolution rate as shown in Table 1, that is, proper response or action were provided by the concerned officials or employees.

Contained at the Standard Procedures Manual of the agency, the Public Affairs and Information Officers at the Regional and District Levels are tasked to manage the office's Customer Feedback Mechanism Program, particularly the Citizen's Feedback Management, and are expected to respond to customers' concerns and assess customer satisfaction through an effective feedback mechanism.

\section{Responsiveness of the complaint management}

Nowadays, bureaucracy is changing its role which calls for greater flexibility towards responsiveness. The complexity of public affairs and its relation to citizens requires the bureaucracy to become more accommodating to the complaints of citizens and become more responsive to their demands (Liao, 2017). This is to ensure that "bureaucratic actions reflect the public desires, ultimately, reconciling the possible conflict between bureaucratic values and democratic ideals". According to Fried (in Liao, 2017)responsiveness is the "the congruence between the goals the organization or administrative system pursues and the goals desired by the people to whom the organization is responsible and under whose authority it operates."

In the article "Government Program Advocacy and the Role of Public Information Officers" (Tibaldo, 2011), the role of the Public Information Officers was defined. It was said that Public Information Officers are responsible for the implementation of public relations activities and communicates important information to the general public.

Secretary Mark A. Villar issued aMemorandum reiterating the designation of District Information Officers (DIO) on July 17, 2017. On the said issuance, the functions of the DIO were identified andspecified that the DIO must have the competency in handling Citizens Feedback Management, CSO/Community Engagement, News/Photo Releases Production, Media Relations, and Publications and Special Projects.

The DIO also ensures that all complaints are acted upon receipt in accordance with the Revised Rules on Administrative Cases in the Civil Service (RRACCS), RA 6713, otherwise known as the "Code of Conduct and Ethical Standards for Public Officials and Employees", and RA 9485, otherwise known as the "Anti Red Tape Act of 2007", and other applicable laws.

The DIO also ensure compliance to the prescribed timelines or period to take action, and to the existing rules and regulation prescribing the schedule of action on queries and complaints contained in various issuances, such as fifteen (15) working days (Republic Act 6713 -Code of Conduct and Ethical Standards of Public Officials and Employees); five (5) working days for simple and ten (10) working days for complex transactions (Republic Act 9485 - Anti-Red Tape Act (ARTA), and seventy-two (72) hours (Executive Order No. 6 Institutionalizing the Citizens Hotline 8888).

Table 2 Period to Take Action

Republic Act 6713 Code of Conduct and Republic Act 9485 Anti Executive Order No.6 Ethical Standards for Public Officials and Red Tape Act $\quad$ Institutionalizing the Citizens Employees Hotline 8888

15 working days

5 working days ( simple) 72 hours

10 working days(complex)

With these existing rules, the DIO is bent on complying with the prescribed timeframe in responding to complaints and other concerns. Non-compliance warrants administrative sanctions such as fines, suspension and other administrative sanctions under existing laws and regulations.

Efficiency in handing complaints

Bureaucracy is efficiency (Erkoc, 2017). According to Alesina and Tabellini (2008) in Erkoc good 
performance can easily be measured and assessed in terms of efficiency. Efficiency is the use of minimum inputs but yielding maximum of outputs in the bureaucracy. This is why the Weberian concept of technical expertise in the assigned task remains influential in the present bureaucratic set up. In fact states that "bureaucrats are preferable to politicians in technical tasks for which ability is more important than effort, or if there is large uncertainty about whether the policymaker possesses the required abilities to fulfil his task". Moreover, they conclude that the policies encompass "highly technical tasks" need to be handed over to the high-skilled public employees..." Therefore, efficiency in the complaints management is another measure of the systems effectiveness. It will measure the effectiveness of the local DPWH office in the management of complaints is on its adherence to the prescribed period to take action relative to complaints resolution. To determine whether the different DPWH Offices conformed to the standards in complaints management, feedbacks must be processed within the prescribed periods to take action as mandated by the different government issuances.

Table 3. Timeliness of Complaints Resolution

\begin{tabular}{|c|c|c|c|c|c|c|}
\hline No. & $\begin{array}{l}\text { Nature of } \\
\text { Complaint/Name } \\
\text { of Complainant }\end{array}$ & $\begin{array}{l}\text { Implementing } \\
\text { Section/Official } \\
\text { Concerned }\end{array}$ & $\begin{array}{l}\text { Date and } \\
\text { Time } \\
\text { Complaint } \\
\text { Received/P } \\
\text { eriod to } \\
\text { Take } \\
\text { Action }\end{array}$ & $\begin{array}{l}\text { Date and Time } \\
\text { Complaint } \\
\text { Resolved/Action Taken }\end{array}$ & $\begin{array}{l}\text { Number of } \\
\text { Days/ Hours } \\
\text { spent for } \\
\text { resolution }\end{array}$ & $\begin{array}{l}\text { Status / } \\
\text { Compliance } \\
\text { to Timeliness }\end{array}$ \\
\hline \multirow[b]{2}{*}{1} & \multirow[t]{2}{*}{ Complaint \# 1} & $\begin{array}{l}\text { Planning and } \\
\text { Design Section }\end{array}$ & $\begin{array}{l}\text { December } \\
12,2017\end{array}$ & December 14, 2017 & \multirow[t]{2}{*}{$\begin{array}{l}\text { Two working } \\
\text { days }\end{array}$} & Resolved \\
\hline & & $\begin{array}{l}\text { Engr. Romeo A. } \\
\text { Ladisla, Assistant } \\
\text { Section Chief }\end{array}$ & $\begin{array}{l}\text { Five } \\
\text { working } \\
\text { days }\end{array}$ & $\begin{array}{l}\text { Advised that the delay } \\
\text { in road construction } \\
\text { were due to adverse } \\
\text { weather conditions and } \\
\text { that the project has two } \\
\text { segments wherein the } \\
\text { Palayan Section was } \\
\text { first completed. }\end{array}$ & & Complied \\
\hline \multirow[b]{2}{*}{2} & \multirow[t]{2}{*}{ Complaint \#2 } & $\begin{array}{l}\text { Construction } \\
\text { Section }\end{array}$ & $\begin{array}{l}\text { November } \\
17,2017\end{array}$ & November 22,2017 & \multirow[t]{2}{*}{$\begin{array}{l}\text { Two working } \\
\text { days }\end{array}$} & Resolved \\
\hline & & $\begin{array}{l}\text { Engr. Rey M. } \\
\text { Laranang, Project } \\
\text { Inspector }\end{array}$ & $\begin{array}{l}\text { Five } \\
\text { working } \\
\text { days }\end{array}$ & $\begin{array}{l}\text { Advised that the project } \\
\text { was already completed } \\
\text { on November } 12,2017 \text {. }\end{array}$ & & Complied \\
\hline \multirow[b]{2}{*}{3} & \multirow[t]{2}{*}{ Complaint \# 3} & $\begin{array}{l}\text { Construction } \\
\text { Section }\end{array}$ & $\begin{array}{l}\text { November } \\
16, \quad 2017, \\
9: 57 \mathrm{AM}\end{array}$ & $\begin{array}{l}\text { November 17, 2017, } \\
\text { 11:55 AM }\end{array}$ & \multirow[t]{2}{*}{$\begin{array}{l}\text { One working } \\
\text { day }\end{array}$} & Resolved \\
\hline & & $\begin{array}{l}\text { Engr. Edwin P. } \\
\text { Dalangin, Project } \\
\text { Inspector }\end{array}$ & $\begin{array}{l}\text { Seventy-two } \\
\text { hours }\end{array}$ & $\begin{array}{l}\text { Constructed earth } \\
\text { ditch/canal to ensure } \\
\text { steady flow of water } \\
\text { run-off from the road } \\
\text { pavement to the curb. }\end{array}$ & & Complied \\
\hline \multirow{2}{*}{4} & \multirow[t]{2}{*}{ Complaint \#4 } & $\begin{array}{l}\text { Planning and } \\
\text { Design Section }\end{array}$ & $\begin{array}{l}\text { September } \\
14, \quad 2017, \\
10: 30 \mathrm{AM}\end{array}$ & $\begin{array}{l}\text { September 15, 2017, } \\
\text { 11:04 AM }\end{array}$ & \multirow[t]{2}{*}{$\begin{array}{l}\text { One working } \\
\text { day }\end{array}$} & Resolved \\
\hline & & $\begin{array}{l}\text { Engr. Romeo A. } \\
\text { Ladisla, Assistant } \\
\text { Section Chief }\end{array}$ & $\begin{array}{l}\text { Seventy-two } \\
\text { hours }\end{array}$ & $\begin{array}{l}\text { Transmitted to the } \\
\text { Regional Office the } \\
\text { requested documents. }\end{array}$ & & Complied \\
\hline \multirow[b]{2}{*}{5} & \multirow[t]{2}{*}{ Complaint \#5 } & $\begin{array}{l}\text { Unified Project } \\
\text { Management } \\
\text { Office (UPMO) }\end{array}$ & $\begin{array}{l}\text { September } \\
5, \quad 2017, \\
3: 29 \mathrm{PM}\end{array}$ & $\begin{array}{l}\text { September 5, 2017, 5:01 } \\
\text { PM }\end{array}$ & \multirow[t]{2}{*}{$\begin{array}{l}\text { One and a } \\
\text { half hours }\end{array}$} & Resolved \\
\hline & & $\begin{array}{l}\text { Engr. Celso G. } \\
\text { Castillo, Chief of } \\
\text { Maintenance } \\
\text { Section }\end{array}$ & $\begin{array}{l}\text { Five } \\
\text { working } \\
\text { days }\end{array}$ & $\begin{array}{l}\text { Referred complaint to } \\
\text { the UPMO. The said } \\
\text { road section was not } \\
\text { within the jurisdiction } \\
\text { of the Office. }\end{array}$ & & Complied \\
\hline 6 & Complaint \#6 & $\begin{array}{l}\text { Planning and } \\
\text { Design Section }\end{array}$ & $\begin{array}{lr}\text { August } & 10, \\
2017, & 9: 29 \\
\text { AM } & \\
\end{array}$ & $\begin{array}{l}\text { August } 10,2017,12: 06 \\
\text { PM }\end{array}$ & $\begin{array}{l}\text { Two and a } \\
\text { half hours }\end{array}$ & Resolved \\
\hline
\end{tabular}




\begin{tabular}{|c|c|c|c|c|c|c|}
\hline No. & $\begin{array}{l}\text { Nature of } \\
\text { Complaint/Name } \\
\text { of Complainant }\end{array}$ & $\begin{array}{l}\text { Implementing } \\
\text { Section/Official } \\
\text { Concerned }\end{array}$ & $\begin{array}{l}\text { Date and } \\
\text { Time } \\
\text { Complaint } \\
\text { Received/P } \\
\text { eriod to } \\
\text { Take } \\
\text { Action }\end{array}$ & $\begin{array}{l}\text { Date and Time } \\
\text { Complaint } \\
\text { Resolved/Action Taken }\end{array}$ & $\begin{array}{l}\text { Number of } \\
\text { Days/ Hours } \\
\text { spent for } \\
\text { resolution }\end{array}$ & $\begin{array}{l}\text { Status / } \\
\text { Compliance } \\
\text { to Timeliness }\end{array}$ \\
\hline & & $\begin{array}{l}\text { Engr. Romeo A. } \\
\text { Ladisla, Assistant } \\
\text { Section Chief }\end{array}$ & $\begin{array}{l}\text { Seventy-two } \\
\text { hours }\end{array}$ & $\begin{array}{l}\text { Advised that all } \\
\text { pertinent documentary } \\
\text { requirements were } \\
\text { previously relayed to } \\
\text { Ms. Tangalin for } \\
\text { submission. }\end{array}$ & & Complied \\
\hline \multirow[b]{2}{*}{7} & \multirow[t]{2}{*}{ Complaint \# 7} & $\begin{array}{l}\text { Planning and } \\
\text { Design Section }\end{array}$ & $\begin{array}{lr}\text { August } 10, \\
2017, \quad 8: 39 \\
\text { AM }\end{array}$ & $\begin{array}{l}\text { August 10, 2017, 11:32 } \\
\text { AM }\end{array}$ & \multirow[t]{2}{*}{ Three hours } & Resolved \\
\hline & & $\begin{array}{l}\text { Engr. Romeo A. } \\
\text { Ladisla, Assistant } \\
\text { Section Chief }\end{array}$ & $\begin{array}{l}\text { Five } \\
\text { working } \\
\text { days }\end{array}$ & $\begin{array}{l}\text { Advised that delay in } \\
\text { completion was due to } \\
\text { adverse weather } \\
\text { condition. }\end{array}$ & & Complied \\
\hline \multirow[b]{2}{*}{8} & \multirow[t]{2}{*}{ Complaint \# 8} & $\begin{array}{l}\text { Unified Project } \\
\text { Management } \\
\text { Office (UPMO) } \\
\end{array}$ & $\begin{array}{lr}\text { June } & 21, \\
2017,10: 48 \\
\text { AM }\end{array}$ & $\begin{array}{l}\text { June } 22,2017, \quad 12: 23 \\
\text { PM }\end{array}$ & \multirow[t]{2}{*}{$\begin{array}{l}\text { One working } \\
\text { day }\end{array}$} & Resolved \\
\hline & & $\begin{array}{l}\text { Engr. Celso G. } \\
\text { Castillo, Chief of } \\
\text { Maintenance } \\
\text { Section }\end{array}$ & $\begin{array}{l}\text { Five } \\
\text { working } \\
\text { days }\end{array}$ & $\begin{array}{l}\text { Referred complaint to } \\
\text { the UPMO. The said } \\
\text { road section was not } \\
\text { within the jurisdiction } \\
\text { of the Office. }\end{array}$ & & Complied \\
\hline \multirow[b]{2}{*}{9} & \multirow[t]{2}{*}{ Complaint \#9 } & $\begin{array}{l}\text { Planning and } \\
\text { Design Section }\end{array}$ & $\begin{array}{lr}\text { June } & 16, \\
2017, & 2: 28 \\
\text { PM } & \\
\end{array}$ & June 16, 2017, 4:03 PM & \multirow[t]{2}{*}{$\begin{array}{l}\text { One and a } \\
\text { half hours }\end{array}$} & Resolved \\
\hline & & $\begin{array}{l}\text { Engr. Romeo A. } \\
\text { Ladisla, Assistant } \\
\text { Section Chief }\end{array}$ & $\begin{array}{l}\text { Five } \\
\text { working } \\
\text { days }\end{array}$ & $\begin{array}{l}\text { Justified based on } \\
\text { available data that the } \\
\text { road section was due for } \\
\text { rehabilitation. }\end{array}$ & & Complied \\
\hline \multirow[b]{2}{*}{10} & \multirow[t]{2}{*}{ Complaint \#10 } & $\begin{array}{l}\text { Maintenance } \\
\text { Section }\end{array}$ & $\begin{array}{lr}\text { May } & 31, \\
2017, & 2: 57 \\
\text { PM } & \\
\end{array}$ & June $6,2017,1: 46$ PM & \multirow[t]{2}{*}{$\begin{array}{l}\text { Four } \\
\text { working } \\
\text { days }\end{array}$} & Resolved \\
\hline & & $\begin{array}{l}\text { Engr. Celso G. } \\
\text { Castillo, Chief of } \\
\text { Maintenance } \\
\text { Section }\end{array}$ & $\begin{array}{l}\text { Five } \\
\text { working } \\
\text { days }\end{array}$ & $\begin{array}{l}\text { Informed that the } \\
\text { Maintenance Section } \\
\text { referred the request to } \\
\text { the UPMO and } \\
\text { instructed the assigned } \\
\text { MPP to prepare a } \\
\text { maintenance schedule } \\
\text { and include the } \\
\text { requested road sections. }\end{array}$ & & Complied \\
\hline \multirow[b]{2}{*}{11} & \multirow[t]{2}{*}{ Complaint \# 11} & $\begin{array}{l}\text { Construction } \\
\text { Section }\end{array}$ & $\begin{array}{l}\text { May 31, } \\
2017\end{array}$ & June 1, 2017, 3:51 PM & \multirow[t]{2}{*}{$\begin{array}{l}\text { One working } \\
\text { day }\end{array}$} & Resolved \\
\hline & & $\begin{array}{l}\text { Engr. Carlos M. } \\
\text { Leabres }\end{array}$ & $\begin{array}{l}\text { Five } \\
\text { working } \\
\text { days }\end{array}$ & $\begin{array}{l}\text { Informed that there } \\
\text { were no projects that } \\
\text { involved drilling of dike } \\
\text { implemented by the } \\
\text { office. }\end{array}$ & & Complied \\
\hline 12 & Complaint \# 12 & $\begin{array}{l}\text { Maintenance } \\
\text { Section }\end{array}$ & $\begin{array}{l}\text { March 14, } \\
2017\end{array}$ & March 15, 2017 & $\begin{array}{l}\text { One working } \\
\text { day }\end{array}$ & Resolved \\
\hline
\end{tabular}




\begin{tabular}{|c|c|c|c|c|c|c|}
\hline No. & $\begin{array}{l}\text { Nature of } \\
\text { Complaint/Name } \\
\text { of Complainant }\end{array}$ & $\begin{array}{l}\text { Implementing } \\
\text { Section/Official } \\
\text { Concerned }\end{array}$ & $\begin{array}{l}\text { Date and } \\
\text { Time } \\
\text { Complaint } \\
\text { Received/P } \\
\text { eriod to } \\
\text { Take } \\
\text { Action } \\
\end{array}$ & $\begin{array}{l}\text { Date and Time } \\
\text { Complaint } \\
\text { Resolved/Action Taken }\end{array}$ & $\begin{array}{l}\text { Number of } \\
\text { Days/ Hours } \\
\text { spent for } \\
\text { resolution }\end{array}$ & $\begin{array}{l}\text { Status / } \\
\text { Compliance } \\
\text { to Timeliness }\end{array}$ \\
\hline & & $\begin{array}{l}\text { Engr. Celso G. } \\
\text { Castillo, Chief of } \\
\text { Maintenance } \\
\text { Section }\end{array}$ & $\begin{array}{l}\text { Five } \\
\text { working } \\
\text { days }\end{array}$ & $\begin{array}{l}\text { Informed that as } \\
\text { reported by the } \\
\text { Maintenance Section, } \\
\text { all safety road signage } \\
\text { was installed during } \\
\text { inspection and that the } \\
\text { sender already met with } \\
\text { the contractor } \\
\text { representative for } \\
\text { compensation on } \\
\text { incidental damages. }\end{array}$ & & Complied \\
\hline \multirow[b]{2}{*}{13} & \multirow[t]{2}{*}{ Complaint \# 13} & $\begin{array}{l}\text { Maintenance } \\
\text { Section }\end{array}$ & $\begin{array}{l}\text { January 20, } \\
2017\end{array}$ & January 26, 2017 & \multirow{2}{*}{$\begin{array}{l}\text { Four } \\
\text { working } \\
\text { days }\end{array}$} & Resolved \\
\hline & & $\begin{array}{l}\text { Engr. Celso G. } \\
\text { Castillo, Chief of } \\
\text { Maintenance } \\
\text { Section } \\
\end{array}$ & $\begin{array}{l}\text { Five } \\
\text { working } \\
\text { days }\end{array}$ & $\begin{array}{l}\text { Informed that already } \\
\text { referred this concern to } \\
\text { PNP San Leonardo for } \\
\text { appropriate action. }\end{array}$ & & Complied \\
\hline \multirow[b]{2}{*}{14} & \multirow[t]{2}{*}{ Complaint \# 14} & $\begin{array}{l}\text { Maintenance } \\
\text { Section }\end{array}$ & $\begin{array}{l}\text { January } 20, \\
2017\end{array}$ & January 26,2017 & \multirow{2}{*}{$\begin{array}{l}\text { Four } \\
\text { working } \\
\text { days }\end{array}$} & Resolved \\
\hline & & $\begin{array}{l}\text { Engr. Celso G. } \\
\text { Castillo, Chief of } \\
\text { Maintenance } \\
\text { Section } \\
\end{array}$ & $\begin{array}{l}\text { Seventy-two } \\
\text { hours }\end{array}$ & $\begin{array}{l}\text { De-clogging of canals } \\
\text { completed }\end{array}$ & & $\begin{array}{l}\text { Non- } \\
\text { compliant }\end{array}$ \\
\hline \multirow[b]{2}{*}{15} & \multirow[t]{2}{*}{ Complaint \#15 } & $\begin{array}{l}\text { Planning and } \\
\text { Design Section }\end{array}$ & $\begin{array}{l}\text { January } 8, \\
2017\end{array}$ & January 9, 2017 & \multirow[t]{2}{*}{$\begin{array}{l}\text { One working } \\
\text { day }\end{array}$} & Resolved \\
\hline & & $\begin{array}{l}\text { Engr. Romeo A. } \\
\text { Ladisla, Assistant } \\
\text { Section Chief }\end{array}$ & $\begin{array}{l}\text { Five } \\
\text { working } \\
\text { days }\end{array}$ & $\begin{array}{l}\text { Explained that the } \\
\text { rehabilitation was } \\
\text { completed in } 2014 \text { and } \\
\text { that several factors may } \\
\text { have contributed to the } \\
\text { wear and tear of the said } \\
\text { thoroughfare. }\end{array}$ & & Complied \\
\hline
\end{tabular}

Table 3 shows specific information required to measure the effectiveness of the complaints management system in the office, such as the nature of complaint, date the feedback was received and acted upon. As can be gleaned on the table, the average days to resolve complaints ranging from one day to five days to resolve which is within the statutory policies in resolving citizens complaints and the applicable rules governing bureaucratic actions on citizens request.

\section{Citizens' Participation in complaint management}

In a democracy, citizens participation role is indispensable in public management (Greitens, 2016) Through citizens participation, public management becomes more dynamic , proactive and is more capable of meeting the challenges of transitory political and administrative problems. Without feedback mechanisms, public management becomes inflexible and fails to meet the challenges of changing political and administrative landscapes According to Ricciardelli A. (2018) there are three models of citizen's participation, presented by the acronym GEM. G stands for democratic Governance, E stands for civic Engagement and $M$ stands for organization Management. By providing them the platform to raise issues and concerns on the agency operation the DPWH provides citizens venue for civic engagement, democratic governance and organization and management vital to agency operation. By institutionalizing an uncomplicated multi-platform complaints and feedback mechanism, the DPWH is reachable to social media users or to the people who prefer to communicate via electronic mail, or through the call-center facility. The administration of the Department's Citizens' Feedback Management Center allows public interaction through social media, and other platforms are recognized as a significant means of addressing concerns raised by its stakeholders.

Another source of feedback is by listening to the comments of the walk-in visitors and through the assessment of the quality of service delivered by the agency to its stakeholders. According to Interviewee 1; "most of the District Engineering Offices in Central Luzon have a common dilemma relative to the 
establishment of an effective feedback mechanism that should strengthen citizen participation in good governance". The Department was aware of this problem and the Stakeholders Relation Service looked for ways in determining clients' needs and in improving customer satisfaction. Figure 3 below presents the agency procedure in handling complaints, to wit;

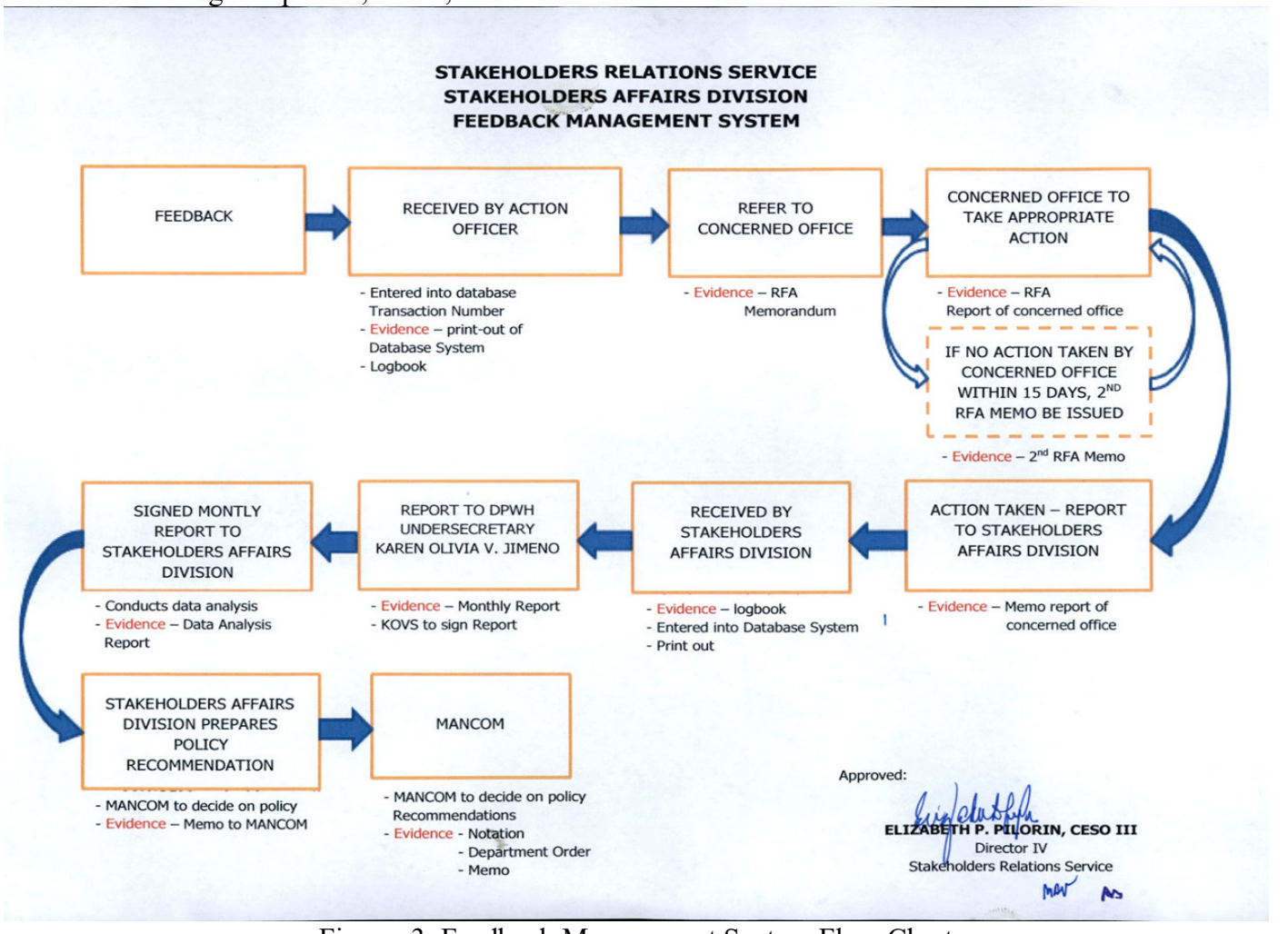

Figure 3. Feedback Management System Flow Chart

Feedbacks received from varied platforms will be referred by the Stakeholders Affairs Division to the different offices of the Department. As seen in Figure 3, the responsible persons and actors in the implementation of the Feedback Management System were identified.

Specified in Department Order No. 32, Series of 2017, systematic guide that will ensure timely and appropriate response to customers' concerns and assesses customer satisfaction through an effective feedback mechanism (Figure 4). The approved process flow also stated the responsibilities, point persons and action to be taken in the resolution of complaints and the DIO is bound to comply with it.

\section{Building Trust}

Another element of effective feedback mechanisms is the ability of the system to build trust while acting on citizen's complaint. Trust as a matter of administration is significant because lack of it will make public governance ineffective. This is based on the premise that the relationship of a citizen with the government should be based on trust not on contracts. Good public services system may not necessarily promote trust, but bad public services system certainly promotes distrust (Bouckaert ,2012 in Vignieri, 2018). According to Mayer et al;1995) trust is "willingness of a party to be vulnerable to the actions of another party based on the expectation that the other will perform a particular action important to the trustor, irrespective of the ability to monitor or control that other party." The common characteristics of trust found in different literatures are vulnerability, risk-taking, and expectations (Hasan,2018). By providing effective complaints mechanism and responsive solutions to the complaints, the DPWH develops strong trust foundation among citizens. The institutionalization of standardized feedback mechanism undoubtedly enhances trust and therefore public governance. The development of multi-sectoral feedback mechanism within the agency began with the Department Order No.169 institutionalizing among others Revised DPWH Customers' Feedback Form, detailing of a Front Desk Officer, received and resolved complaints on time. 


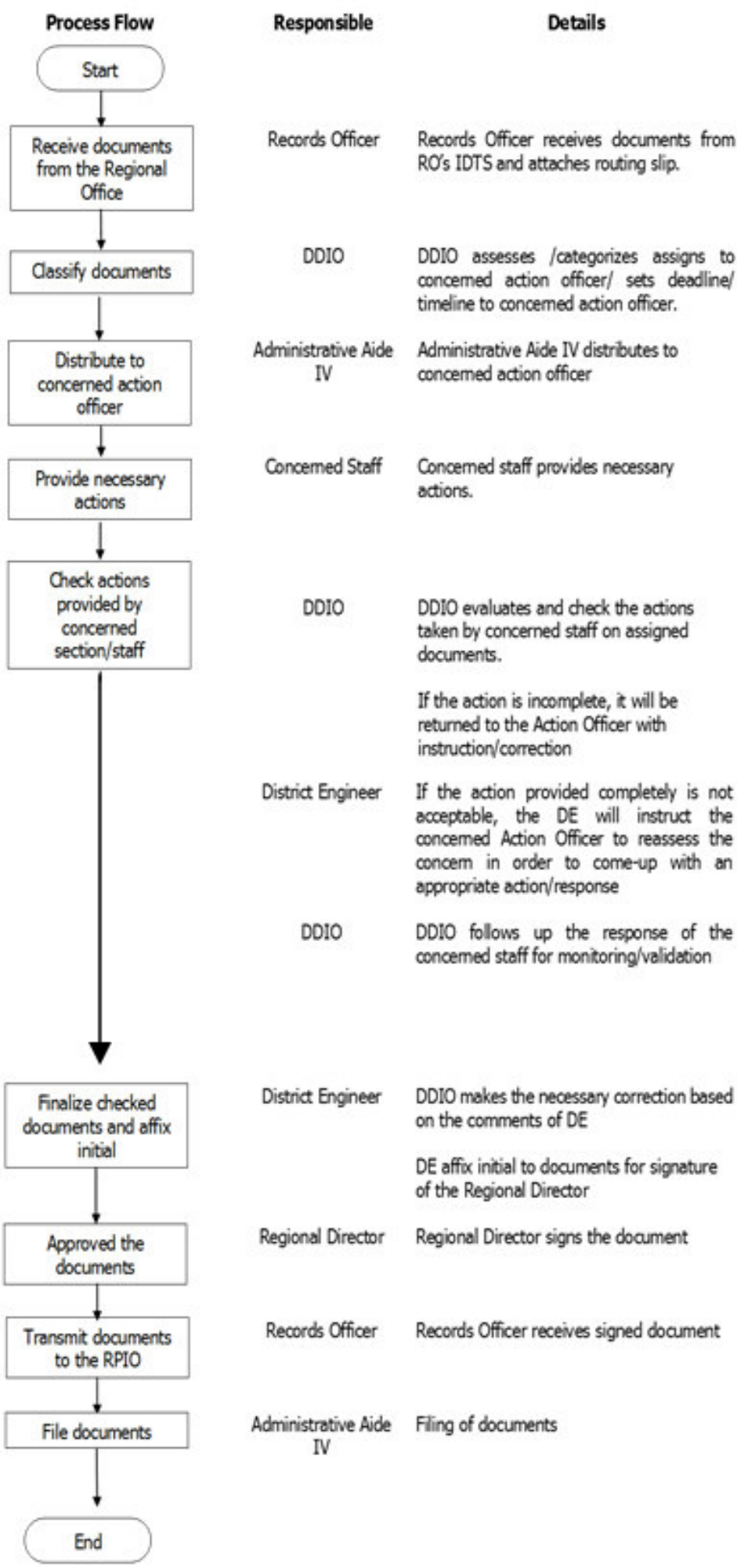

Figure 4 Citizen's Feedback Mechanism for District Engineering Offices

Eight (8) people expressed their disappointment in the implementation of various road projects, while there were two (2) received requests made by individuals that were acted on by the agency.

All complaints received in 2017 were resolved and properly addressed by the concerned implementing 
sections and officials, but there was only $93.33 \%$ compliance to the period to take action, or one (1) out of fifteen (15) complaints exceeded the given timeframe.

The concern that exceeded the prescribed period to take action was lodged on January 20, 2017 at the Contact Center ng Bayan (CCB) platform of the Civil Service Commission, the agency that was previously receiving the complaints addressed to the Presidential Action Complaints Center. This was resolved on January 26, 2017, one (1) day longer than the prescribed three (3) working days period to take action. The request for assistance for the de-clogging of canals, Sta. Rosa, Nueva Ecija was not readily acted upon by the assigned Maintenance Point Person in the area.

Thus, it was determined that the DIO coordinated the received complaints to the specific action officers promptly and complied in accordance with the standard process flow contained in the Customer Feedback Mechanism that was institutionalized by the DPWH. It was also reported that there was $100 \%$ resolution of complaints, although there was a failure in accomplishing $100 \%$ compliance to the mandated period to take action.

In summary, the manner the agency handles the complaints lodged by citizens is effective as measured by the qualitative parameters of principles of fairness, accessibility, responsiveness, and efficiency, citizens' participation, analysis of strengths and weaknesses, building of trust and observance of processes and institutional procedures. Alongside with this is the quantity of complaints received and resolved within the year 2017 which showed a 100 percent resolution within the prescribed periods mandated by statutory rules on complaints resolution and management applicable to public sector organization. Civic engagement is an effective tool to promote democracy and enhance open government. They are proven to create positive political outcomes and policy implementation results thereby boosting social capital and economic prosperity ( Lee S.Y., Díaz-Puente J.M., Martin S. (2018).

\section{Perceived Limitations of the Nueva Ecija $2^{\text {nd }}$ District Engineering Office in managing complaints}

The occurrence of one (1) non-compliant complaint that exceeded the allowed time to take action proved that there were certain limitations encountered by the DIO in solving it. It also showed that there were instances that the DIO may not promptly facilitate the response due to the following reasons:

- Lack of cooperation from the implementing unit. This risk is likely to happen specially when the concerned Project Engineer or Section Chief fail to provide the appropriate response to the complaint and could result in unresolved complaints.

- Lack of service vehicles to verify complaints. There are instances that a site inspection or survey must be made to validate the raised issue or grievance. The absence of service vehicles may result in the delay in response and to the preparation of the Request for Action (RFA) Form.

- Lack of support from superiors. In this case, the functions of the DIO may be belittled by a superior who may ignore the complaint by not taking any action for its immediate resolution.

- Limitations due to insufficient support personnel who will assist the DIO. The DIO must also attend to the needs of the walk-in clients who seek frontline services. But another concern is that the DIO must also monitor the Public Assistance and Complaints Desk (PACD) and the designated Front Desk Office who will attend to the needs of the customers (Interviewee 2). The lack of personnel at the PACD is in congruent to the provision of the Anti-Red Tape Act (ARTA) of 2007 and most of the times, clients come in and out of the office unattended resulting to poor customer satisfaction. Although the District Engineering Office designated a Front Desk Officer, the need for some full-time personnel to man the desk is required to satisfy the requirements of the ARTA law. The Front Desk Office that will be assigned must be knowledgeable in addressing the concerns of the customers and is acquainted with the operations of the District Engineering Office.

With the above-cited time prescriptions and limitations on the part of the DIO, there are instances that the DIO may not successfully relay to its stakeholders the appropriate and accurate responses to their queries.

\section{Summary, Conclusions, and Recommendations}

The overall objective of this study was to analyze the complaint management program of the DPWH Nueva Ecija 2nd District Engineering Office. In undertaking this study, the researcher interviewed key personnel of the DPWH Regional and District Engineering Offices with the overall aim to validate whether the office complied in the customer management program of the Department. Existing literature such as issuances, complaint feedbacks and related forms were reviewed and analyzed.

The findings of the study revealed that the local DPWH office conformed to the standard process flow in Citizens Feedback Management and resolved all the fifteen (15) complaints received. However, one measure of efficiency that must be observed was the prescribed period to take action. One (1) complaint was found to be non-complying since it exceeded the given timeline.

The research also showed that the office designated the right person to communicate the programs and 
activities of the agency. Still, the technical nature of the infrastructure related complaints and other matters involved in complaints management, the aptitude of the present DIO is deemed inadequate.

Finally, it was found out that there were certain drawbacks that the office has encountered that resulted to the delay in acting on the received complaint.

The importance of the management of complaints is acknowledged by Nueva Ecija $2^{\text {nd }}$ District Engineering Office as a necessary part of the Customer Feedback Management Program and service delivery. In fact, the timeliness and appropriateness of complaints response are considered a mark of good governance.

Although the commitment and initiative of the designated DIO in ensuring $100 \%$ resolution of complaints promptly is unquestionable, still he was deemed unfit if the parameters or qualification standards of an ideal Complaints Handling Officer is used as the basis for the selection and appointment. Admittedly, he lacked the technical skills and training in effectively handling the complaints but managed the resolution of all received complaints.

There were perceived limitations that the DIO may encounter that could affect the timely resolution of complaints. The management need to consider these risks to prevent any incident of delayed or unresolved complaints.

Thus, to fully assess the efficiency of the DIO in the management of complaints, it is necessary to evaluate the capabilities of the designated DIO until such time that a permanent position is made available, and a qualified professional will perform its specific functions.

It is further recommended that the DPWH create a specific item for District Information Officers and hire qualified personnel that has the adequate training and experience to successfully publicize or impart the strategies and programs of DPWH to its stakeholders.

\section{Acknowledgment}

I would like to thank the management of DPWH Nueva Ecija $2^{\text {nd }}$ District Engineering Office in Cabanatuan City, and the Regional Public Affairs and Information Officer of DPWH Regional Office No. 3 in City of San Fernando, Pampanga, for their contributions to this study and for the valuable data and information they have provided.

\section{References}

Agency for Healthcare Research and Quality(2013). "Mixed Methods: Integrating Quantitative and Qualitative Data Collection and Analysis While Studying Patient-Centered Medical Home Models" Australian/New Zealand Standard (2014). AS/NZS 10002:2014 Guidelines for Complaint Management in Organizations

Erkoc T.E. (2017) Bureaucracy and Efficiency. In: Farazmand A. (eds) Global Encyclopedia of Public Administration, Public Policy, and Governance. Springer, Cham

Gabriel, A. G. (2017). Transparency and accountability in local government: levels of commitment of municipal councilors in Bongabon in the Philippines. Asia Pacific Journal of Public Administration, 39(3), 217-223. https://doi.org/10.1080/23276665.2017.1368902

Gabriel, A. G., \& Gutierrez, M. P. (2017). Praxis in Local Legislative Governance: Measure of Organizational Effectiveness of the Component Cities in Nueva Ecija, Philippines. Asia Pacific Journal of Multidisciplinary Research, 5(2).

Gabriel A. G. \& Ong D. (2018) Linking Transparency and Accountability to Local Legislative Performance in the Province of Nueva Ecija in the Philippines Journal of Public Administration and Governance Vol 8, No $2(2018)$

Greitens T.J. (2016) Citizen Participation in Public Management. In: Farazmand A. (eds) Global Encyclopedia of Public Administration, Public Policy, and Governance. Springer, Cham

Greitens T.J. (2016) Citizen Participation in Public Management. In: Farazmand A. (eds) Global Encyclopedia of Public Administration, Public Policy, and Governance. Springer, Cham

Government of Hong Kong SAR (2009): "Serving the Community by Improving Customer Service: A Guide to Complaints Handling and Public Enquiries"

Hasan A.R. (2018) Governance and Trust. In: Farazmand A. (eds) Global Encyclopedia of Public Administration, Public Policy, and Governance. Springer, Cham

Johnson, R.B., \& Turner, L.A., (2003). "Data Collection Strategies in Mixed Methods Research",

Johnson, R. B., \& Onwuegbuzie, A. J. (2004). "Mixed Methods Research: A Research Paradigm Whose Time Has Come"

Lawton A., Rayner J. (2016) Managerial Functions in the Public Sector. In: Farazmand A. (eds) Global Encyclopedia of Public Administration, Public Policy, and Governance. Springer, Cham

Lee S.Y., Díaz-Puente J.M., Martin S. (2018) Open Government influence on Social Prosperity. In: Farazmand A. (eds) Global Encyclopedia of Public Administration, Public Policy, and Governance. Springer, Cham 
Liao Y. (2017) Bureaucracy Responsiveness. In: Farazmand A. (eds) Global Encyclopedia of Public Administration, Public Policy, and Governance. Springer, Cham

Mayer M., Kenter R. (2016) Public Sector Collaboration and Social Policy. In: Farazmand A. (eds) Global Encyclopedia of Public Administration, Public Policy, and Governance. Springer, Cham

McInerney C., Finn C. (2016) Leadership Challenges in Civic Engagement. In: Farazmand A. (eds) Global Encyclopedia of Public Administration, Public Policy, and Governance. Springer, Cha

Ombudsman in Western Australia(2010). "Guidance for Complaint Handling Officers"

Palumbo R. (2017) Participatory Governance. In: Farazmand A. (eds) Global Encyclopedia of Public Administration, Public Policy, and Governance. Springer, Cham

Ricciardelli A. (2018) Governance, Local Communities, and Citizens Participation. In: Farazmand A. (eds) Global Encyclopedia of Public Administration, Public Policy, and Governance. Springer, Cham

Tibaldo, Joel Arthur P. (2011). "Government Program Advocacy and the Role of Public Information Officers"

Vignieri V. (2018) Performance Management in the Public Sector. In: Farazmand A. (eds) Global Encyclopedia of Public Administration, Public Policy, and Governance. Springer, Cham Related Issuances:

DPWH Department Order No. 53, Series of 2014, May 21, 2014

DPWH Customers' Feedback Form

DPWH Unnumbered Memorandum Order, July 17, 2017:"Designation of Information Officers"

DPWH Department Order No. 22, Series of 2017, February 28, 2017: Implementation of the Quality Management System (QMS) Manual in conformance with the requirements of ISO 9001:2015",

DPWH Department Order No. 32, Series of 2017, February 28, 2017: Issuance of a Standard Procedures Manual for the Regional and District Engineering Offices",

DPWH Department Order No. 169, Series of 2016."Revised DPWH Customers' Feedback Form”, August 25, 2016

Republic Act 6713 Code of Conduct and Ethical Standards of Public Officials and Employees", February 20, 1989

Republic Act 9485 Anti-Red Tape Act (ARTA)", June 2, 2007

Executive Order No. 6 - Institutionalizing the 8888 Citizens' Complaint Hotline and Establishing the 8888 Citizens' Complaint Center", October 14, 2016

CSC Revised Rules on Administrative Cases in the Civil Service (RRACCS)", November 21, 2011

Qualification Standards (Revised 1997)", Civil Service Commission, January 1997 
Resource Person:

Interviewee Number 1: Mrs. Adora DL. Sunga, Regional Public Affairs Information Officer, DPWH Pampanga Interviewee Number 2: Department Information Officer Second Engineering District, Cabanatuan City, Philippines

\section{Complaint Table and its Code}

Complaint 1 FB-CFMC-20173692 - Complaint filed by an anonymous person RE: Status of rehabilitation of San Roque Bridge, San Isidro, NE

Complaint 2 LR-CFMC-20173320 - Complaint by Mr. BoyetMagtalas RE: Road Rehabilitation in Jaen, Nueva Ecija

Complaint 3 LR-CFMC-20172002 - Request for documents of PB Reymundo E. De Leon of Brgy. Bugnan, Gabaldon, NE

Complaint 4 FB-CFMC-20172797 - Complaint of a person whose name was withheld upon request RE: Road condition of Maharlika Highway from Bucana, Gapan City to Sta. Rosa, NE

Complaint 5 LR-CFMC-20172521 - Complaint of Ms. Zenaida G. Tangalin RE: Road Right-of-Way Compensation claim, Laur, NE

Complaint 6 CC-CFMC-20172495 - Complaint of Mark Sandoval RE: Alleged delayed road construction, Bangad, Cabanatuan City

Complaint 7 CC-CFMC-20171936 - Complaint of a concerned citizen RE: Road Condition of Maharlika Highway, Gapan-San Leonardo Section

Complaint 8 FB-CFMC-20171903 - Complaint of a person whose name was withheld upon request RE: Rehabilitation of Road, Brgy. Imelda, Palayan City

Complaint 9 FB-CFMC-20171752 - Letter request sent by Gian HernalLajom, forwarding the request of VM Boyet de Guzman Angeles, Sta. Rosa, NE

Complaint 10 FB-CFMC-20171747 - Complaint of a person whose name was withheld upon request RE: Drilling of dike in Cabiao, NE

Complaint 11 LR-CFMC-20170754 - Complaint of a person whose name was withheld upon request RE: Lack of early warning devices on the road construction, Sta. Rosa, NE

Complaint 12 Direct Memo - Complaint of Mr. Roland Garcia RE: Use of National Highway in San Leonardo, NE for palay drying

Complaint 13 Direct Memo - Request of Mr. Dennis I. Angeles II for assistance for the de-clogging of canals, Sta. Rosa, NE

Complaint 14 FB-CFMC-20162572 - Complaint of a person whose name was withheld upon request RE: Rehabilitation of NE-Aurora Rd., Bangad to Pangatian Section, Cabanatuan City 